\title{
LONGITUDINAL VARIATION IN SELECTED WOOD PROPERTIES OF ORIENTAL BEECH AND CAUCASIAN FIR
}

\author{
Elif Topaloglu ${ }^{1, \star}$, Emir Erisir $^{2}$
}

\author{
In memoriam of Dr. Thomas C. MANNES
}

\begin{abstract}
In this study, several wood properties were investigated along with the longitudinal direction for oriental beech and caucasian fir trees grown in Turkey. Wood density, compression strength parallel to grain, chemical characteristics (holocelluose, celluose, lignin), fiber dimensions (fiber length, fiber width, fiber lumen width, fiber cell wall thickness) were measured from the sapwood of the discs taken at the stem heights of 1,30; 6,30 and 12,30 meters. Both wood species showed clear trends in wood properties along longitudinal direction. For both wood species, the highest values in density, compression strength, volumetric shrinkage and swelling were at $1,30 \mathrm{~m}$ stem height, and the investigated parameters decreased along with the stem height, while longitudinal shrinkage and swelling percentage increased. The highest cellulose content was found at 1,30 $\mathrm{m}$ stem height, and the highest lignin content was found at $12,30 \mathrm{~m}$ stem height for both wood species. The longest fibers and the thickest fiber walls were determined at $1,30 \mathrm{~m}$ stem height in both wood species. These results clearly indicated that stem height greatly affected the investigated wood properties for both wood species.
\end{abstract}

Keywords: Abies nordmanniana, Fagus orientalis, longitudinal variation, stem height, wood properties.

\section{INTRODUCTION}

The importance of variability in wood properties within tree has often been emphasized in the literature. Zobel and van Buijtenen (1989), the most important reference on this subject, explained in detail the changes in a number of wood properties both radial (from the center to the bark) and longitudinal (from the base to the top) direction in the tree. Lachenbruch et al. (2011) reported that the anatomical, chemical, physical and mechanical properties of wood vary considerably between plant parts (such as main stems, branches and roots) and within any plant part. Many publications describe the various longitudinal variation patterns within trees. The recent work of Kiaei and Farsi (2016) for Persian silk wood (Albizzia julibrissin) illustrated wood density, modulus of elasticity and modulus of rupture in bending decreased from base to top with height, and Longui et al. (2016) for Astronium graveolens showed specific gravity was higher at the base of tree and shear parallel to grain did not vary in analyzed heights.

When the publications are examined, it is seen that there are more studies in conifers than hardwoods. Machado and Cruz (2005) determined a decreasing tendency of mechanical properties (bending strength, modulus of elasticity parallel to grain, compression strength parallel to grain, tension strength perpendicular to grain) of maritime pine because of the growing presence of juvenile wood. Molteberg and Høibø (2006) found that fiber width decreased, while basic density and fiber length of norway spruce increased with increasing height in the tree. Cato et al. (2006) stated that wood from

\footnotetext{
${ }^{1}$ Architecture and Urban Planning Department, Technical Sciences Vocational School, Giresun University, Giresun, Turkey. ${ }^{2}$ Forest Industry Engineering Department, Faculty of Forestry, Karadeniz Technical University, Trabzon, Turkey.

"Corresponding author: elif.topaloglu@giresun.edu.tr

Received: 18.02.2017 Accepted: 07.01. 2018
} 
the crown in Pinus radiata has a lower density because of a decrease in cell wall thickness. Antony et al. (2010) reported specific gravity of Pinus taeda, decreased in a nonlinear trend with tree height. A decreased trend of wood density, shrinkage and swelling (tangential and volumetric) along the stem height for Larix decidua trees was reported by Ay et al. (2012). Moreover, mature norway spruce trunkwood had higher hydraulic efficieny and bending stiffness than juvenile wood from the tree top, while both wood types had similar ring densities (Rosner and Karlsson 2011, Rosner 2013).

In contrast to these findings, Lukašek et al. (2012) working on grand fir determined that the vertical position did not obviously affect the size of the shrinkage. Regarding the vertical variation in wood properties of hardwoods, Rueda and Williamson (1992) studied the vertical variation in the radial increase in specific gravity of Ochroma pyramidale, and observed a linear increase with radial distance at any given height. Poplar and eucalyptus species are among the most studied tree species in angiosperms. For example, Kord et al. (2010) found that within tree wood density and shrinkage values of Populus euramericana decreased along the stem, from the base to the upwards at $5 \%, 25 \%$, $50 \%$, and $75 \%$ of total tree height. Contrary to the usual trend, Githiomi and Kariuki (2010) reported that basic density of Eucalyptus grandis decreased from base to breast height and then increased a maximum at $60 \%$ height point.

The literature contains many references to the longitudinal variation (from the base to the top) of several wood properties in conifers and hardwoods. No information is available about the variation of physical, mechanical and chemical wood properties of oriental beech and caucasian fir naturally grown in Turkey. However, oriental beech is used in various places in the Turkish forest products industry (Bozkurt and Erdin 1997) and caucasian fir constitutes $81 \%$ of the forest tree seeds exported by the Forest Trees Seeds and Tree Breeding Research Directorate in Turkey (Karasahin et al. 2002). It is also important for end user to know how the wood properties of these species have economic importance vary at different heights in the tree. Nevertheless, information about the longitudinal variation of physical, mechanical, and chemical properties for oriental beech and caucasian fir grown in Turkey is still lacking. To use these tree species more effectively in the forest product industry, the wood properties mentioned above need to be determined.

The objective of this study was to examine the variation of wood density, compression strength parallel to grain, chemical characteristics (holocelluose, celluose, lignin), fiber dimensions (fiber length, fiber width, fiber lumen width, fiber cell wall thickness) along longitudinal position of oriental beech and caucasian fir stems. These wood properties along the stem height were also evaluated.

\section{MATERIALS AND METHODS}

\section{Trees and test samples}

Wood samples of oriental beech (Fagus orientalis Lipsky.) and caucasian fir (Abies nordmanniana (Stev.) Spach.) were obtained from the forest stands located between $40^{\circ} 55^{\prime} 03^{\prime}-41^{\circ} 04^{\prime} 43^{\prime \prime} \mathrm{N}$ latitude and $38^{\circ} 23^{\prime} 33^{\prime \prime}-41^{\circ} 45^{\prime} 46^{\prime \prime}$ E longitude in the Black Sea region of Turkey. The trees of both species were randomly selected to represent other trees in the stands with similar diameters at breast height and with similar tree heights. Characteristics of the test tree are indicated in Table 1. The six trees felled using destructive method and total tree height measured. Discs are $15 \mathrm{~cm}$ height were cut at 1,30 $\mathrm{m} ; 6,30 \mathrm{~m}$ and $12,30 \mathrm{~m}$ avoiding branches and defects. After, from the discs, heartwood was removed and $20 \mathrm{~mm}$ wide strips were cut from sapwood using band saw. Small clear specimens with dimensions of $20 \times 20$ $\times 30 \mathrm{~mm}($ radial $\times$ tangential $\times$ longitudinal) were then cut from these strips using circular saw (Figure 1). The specimens were then conditioned a conditioning room at $20^{\circ} \mathrm{C}$ temperature and $65 \%$ relative humidity until average moisture content reaches $12 \%$ (ISO 554, 1976). 
Table 1. Characteristics of the test tree.

\begin{tabular}{|c|c|c|c|c|}
\hline \multirow{2}{*}{ Species } & Tree No & $\begin{array}{c}\text { Diameter at breast } \\
\text { height }(\mathrm{cm})\end{array}$ & $\begin{array}{c}\text { Total tree } \\
\text { height }(\mathrm{m})\end{array}$ & Cambial age at breast height \\
\hline \multirow{3}{*}{ Oriental beech } & 1 & 31,0 & 22,0 & 49 \\
\cline { 2 - 5 } & 2 & 30,0 & 22,6 & 50 \\
\cline { 2 - 5 } & 3 & 33,2 & 23,3 & 53 \\
\hline \multirow{3}{*}{ Caucasian fir } & 1 & 23,0 & 20,0 & 40 \\
\cline { 2 - 5 } & 2 & 24,0 & 21,5 & 38 \\
\cline { 2 - 5 } & 3 & 23,5 & 21,0 & 39 \\
\hline
\end{tabular}
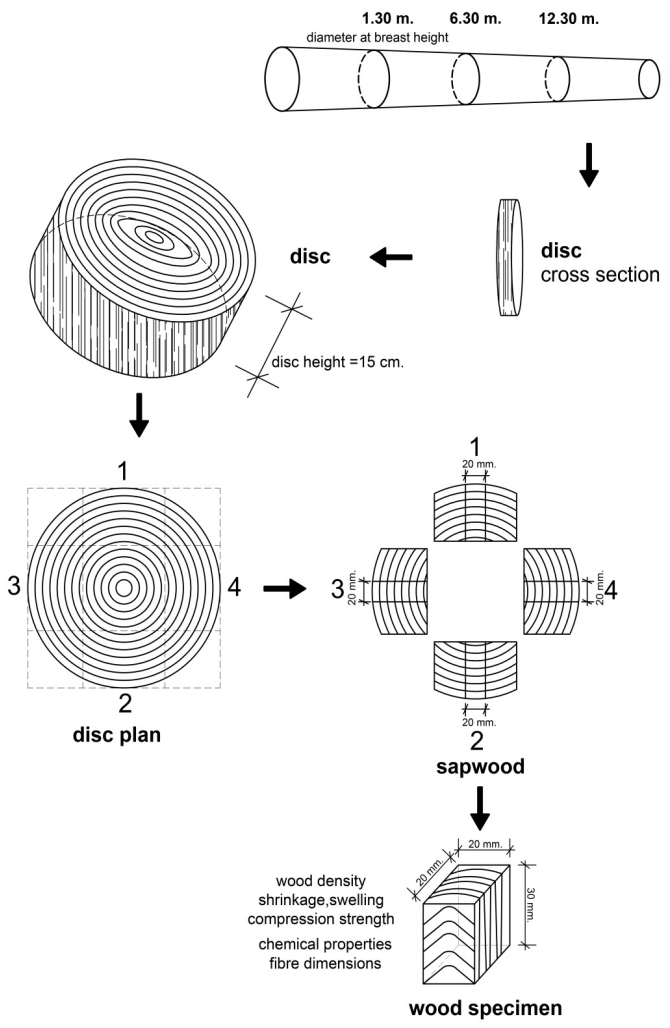

Figure 1. Tree sampling and position of wood samples in the tree.

\section{Wood density, shrinkage, swelling measurements and compression strength test}

Air-dry density $\left(D_{12}\right)$, shrinkage percentage [tangential $\left(\beta_{t}, \%\right)$, radial $\left(\beta_{r}, \%\right)$, longitudinal $\left(\beta_{l}\right.$, $\%$ ), volumetric shrinkage percentage $(\beta, \%)$ ], swelling percentage [tangential $(\alpha, \%)$, radial $(\alpha$, $\%)$, longitudinal $(\alpha, \%)$, and volumetric swelling percentage $(\alpha, \%)$ ] of the wood were determined according to the ISO 3131 (1975), ISO 4469 (1981), ISO 4858 (1982), ISO 4859 (1982), ISO 4860 (1982), respectively. Weight and volume of wood specimens with $12 \%$ moisture were measured. 
Air-dry density was calculated the ratio of air dry mass to air dry volume. Weight and dimension of wood specimens with oven dry ( $0 \%$ moisture content) and green condition (above the fiber saturation point) were measured. Shrinkage percentage was calculated the ratio of decrease in dimension to green dimension, and swelling percentage was calculated the ratio of increase in dimension to green dimension. Volumetric shrinkage and swelling percentages were calculated by summing the tangential, radial and longitudinal shrinkage and swelling percentages (Bektas and Guler 2001). Compression strength parallel to the grain $(C S)$ was determined on universal testing machine and according to the principles of ISO 3787 (1976). Thirty measurements were performed to determine the experiments belonging to each group.

\section{Chemical analyses}

The determination of the wood cell composition was carried out according to TAPPI Test Methods: Sampling and Preparing Wood for Analysis (TAPPI standard 2012), Solvent Extractives of Wood and Pulp (TAPPI standard 2007) and Acid-Insoluble Lignin in Wood and Pulp (TAPPI standard 2011). To determine the holocellulose content of the wood, Wise's Chloride method was used. In this method, pre-extracted wood particles were reacted with acidified sodium chloride $(\mathrm{pH} 4)$ at $70-80^{\circ} \mathrm{C}$ for $3-5$ hours (Wise et al. 1946). Kürschner-Hoffner's approach, in which wood particles are directly treated with nitric acid in ethyl alcohol mixture, was used for to determine the cellulose content (Browning 1967, Fengel and Wegener 1989).

\section{Fiber measurements}

For fiber dimension determinations, the wood samples without bark were chipped by hand. As using in the industrial purposes, all parts of wood were chipped as if there was no difference between earlywood and latewood. Then, about 3-4 grams small slivers were macerated with $60 \mathrm{ml}$ glacial acetic acid/hydrogen peroxide solution $(\mathrm{v} / \mathrm{v})$ in an oven at $60^{\circ} \mathrm{C}$ for 12 hours (Tavares et al. 2011). After completion of the maceration, the delignified fibers were washed by distilled water, filtrated and then placed in a small flask with distilled water. To disintegrate fiber bundles, the suspension was gently mixed by a magnetic stirrer to avoid fiber breaking and then the fiber suspension was filtrated again. Fiber suspension was consisted of largely tracheids, and less rays and epithelial cells for caucasian fir but only tracheid cells were measured. On the other hand, for oriental beech samples, fiber suspension with vessel elements, fibers, rays and longitudinal parenchyma had a more complex system than the former one but only fibers were selected and measured. Finally, three slides were prepared for each measurement and the images of the slides under a calibrated light microscope (PROJECTINA 4014 Forensic Microscope) were recorded by a semiprofessional camera (Akita DC-200C model 3.3 mega pixel digital camera). The measurements of fiber dimensions from the light microscope images were performed by the help of a digital analyze program (Digimizer).

\section{Statistical analysis}

Analysis of variance (ANOVA) for all wood properties was performed the basis of the $95 \%$ confidence interval. Significant differences among stem heights were determined by Duncan's homogeneity groups. Statistical analysis was performed using the SPSS 22.0 version.

\section{RESULTS AND DISCUSSION}

\section{Wood density, shrinkage and swelling values}

The mean and standard deviation values for each stem height, and summary of variance analysis for air dry density, compression strength, shrinkage and swelling of oriental beech and caucasian fir are given in Table 2 and Table 3. 
Table 2. Air dry density, compression strength, shrinkage and swelling values of wood specimens.

\begin{tabular}{|c|c|c|c|c|c|c|c|}
\hline \multirow{3}{*}{$\begin{array}{l}\text { Wood } \\
\text { Properties }\end{array}$} & \multirow{3}{*}{ Unit } & \multicolumn{3}{|c|}{ Oriental beech } & \multicolumn{3}{|c|}{ Caucasian fir } \\
\hline & & \multicolumn{6}{|c|}{ Stem height (m) } \\
\hline & & 1,30 & 6,30 & 12,30 & 1,30 & 6,30 & 12,30 \\
\hline$D_{12}$ & $\mathrm{~kg} / \mathrm{m}^{3}$ & $730(20)^{\mathrm{s}^{4}}$ & $690(10)^{b}$ & $650(40)^{c}$ & $400(30)^{x}$ & $370(10)^{\mathrm{y}}$ & $350(20)^{z}$ \\
\hline CS & $\mathrm{MPa}$ & $59,26(5,12)^{\mathrm{a}}$ & $55,34(5,79)^{b}$ & $54,06(5,90)^{b}$ & $39,82(1,86)^{x}$ & $38,55(5,57)^{\mathrm{x}}$ & $33,02(3,88)^{y}$ \\
\hline$\beta_{t}$ & $\%$ & $11,11(0,40)^{\mathrm{a}}$ & $10,58(0,92)^{b}$ & $10,31(0,74)^{b}$ & $8,01(0,31)^{x}$ & $7,67(0,16)^{y}$ & $6,96(0,12)^{z}$ \\
\hline$\beta_{\mathrm{r}}$ & $\%$ & $5,49(0,31)^{\mathrm{a}}$ & $5,13(0,53)^{b}$ & $4,68(0,27)^{c}$ & 4,00 & 3,75 & $3,37(0,11)^{z}$ \\
\hline$\beta_{1}$ & $\%$ & $0,30(0,05)^{b}$ & $0,32(0,05)^{\mathrm{ab}}$ & $0,34(0,05)^{\mathrm{a}}$ & $0,27(0,03)^{z}$ & $0,32(0,06)^{y}$ & $0,35(0,08)^{x}$ \\
\hline$\beta_{v}$ & $\%$ & $16,90(0,65)^{\mathrm{s}}$ & $16,04(1,32)^{b}$ & $15,33(0,87)^{c}$ & $12,28(0,59)^{x}$ & $11,74(1,03)^{\mathrm{y}}$ & $10,68(0,51)^{z}$ \\
\hline$a_{t}$ & $\%$ & $13,96(0,50)^{\mathrm{a}}$ & $11,92(0,60)^{b}$ & $11,31(0,65)^{c}$ & $8,33(0,72)^{x}$ & $7,98(0,73)^{\mathrm{y}}$ & $7,39(0,29)^{z}$ \\
\hline$a_{1}$ & $\%$ & $6,12(0,74)^{\mathrm{a}}$ & $5,69(0,47)^{b}$ & $5,57(0,34)^{b}$ & $4,02(0,36)^{x}$ & $3,74(0,33)^{y}$ & $3,48(0,22)^{z}$ \\
\hline$\alpha_{1}$ & $\%$ & $0,31(0,03)^{c}$ & $0,33(0,02)^{b}$ & $0,35(0,03)^{\mathrm{a}}$ & $0,34(0,06)^{y}$ & $0,39(0,08)^{x}$ & $0,44(0,07)^{x}$ \\
\hline$a_{v}$ & $\%$ & $20,40(1,05)^{\mathrm{a}}$ & $17,95(0,79)^{b}$ & $17,23(0,71)^{c}$ & $12,69(0,88)^{x}$ & $12,11(0,85)^{y}$ & $11,31(0,35)^{z}$ \\
\hline
\end{tabular}

*Values in parentheses are standard deviations.

Different letters (a-c) and (x-z) within a line indicate significant differences between heights at $95 \%$ confidence level.

Table 3. Summary of variance analysis for air dry density, compression strength, shrinkage and swelling values

\begin{tabular}{|c|c|c|}
\hline \multirow{2}{*}{ Wood properties } & \multicolumn{2}{|c|}{ Significant level $(P)$} \\
\cline { 2 - 3 } & Oriental beech & Caucasian fir \\
\hline $\mathrm{D}_{12}$ & 0,000 & 0,000 \\
\hline $\mathrm{CS}$ & 0,002 & 0,000 \\
\hline$\beta_{\mathrm{t}}$ & 0,000 & 0,000 \\
\hline$\beta_{\mathrm{r}}$ & 0,000 & 0,000 \\
\hline$\beta_{1}$ & 0,023 & 0,000 \\
\hline$\beta_{\mathrm{v}}$ & 0,000 & 0,000 \\
\hline$\alpha_{t}$ & 0,000 & 0,000 \\
\hline$\alpha_{\mathrm{r}}$ & 0,000 & 0,000 \\
\hline$\alpha_{1}$ & 0,000 & 0,001 \\
\hline$\alpha_{\mathrm{v}}$ & 0,000 & 0,000 \\
\hline
\end{tabular}

The results show that the lowest and highest air dry density for oriental beech and caucasian fir were found to be $650-730$ and $350-400 \mathrm{~kg} / \mathrm{m}^{3}$, respectively. Wood density values of oriental beech and caucasian fir are stated to be as $690-770 \mathrm{~kg} / \mathrm{m}^{3}$ by Topaloglu et al. (2016), and $420 \mathrm{~kg} / \mathrm{m}^{3}$ by Usta (2004), respectively. Wood density is one of the most important physical properties of wood (Wiedenhoeft and Miller 2005), and it is related to other wood properties such as strength, stiffness and efficiency in use (Saranpää 2003). Lachenbruch and McCulloh (2014) reviewed wood density is correlated with hydraulic and mechanical performance of woody plants, and is also related to hydraulic safety in the living tree (Rosner 2013). Analyses of variance showed that there was a significant difference $(P<0,05)$ among the stem heights, and air dry density decreased with increasing stem height for both wood species. Similar results were reported for Pinus sylvestris, Betula pendula and Betula pubescens by Repola (2006), for Tectona grandis Izekor et al. (2010), for Corylus colurna by Zeidler (2012), for Abies alba by Rodrigo et al. (2013), for Pinus taeda by Yu et al. (2014), for Albizza julibrissin by Kiaei and Farsi (2016), and for Neolamarckia cadamba by Mahmud et al. (2017). In contrast, Molteberg and Høibø (2006) reported an increase of basic density with vertical position in the norway spruce trees. Moreover, in a given cambial age for norway spruce, Jyske et al. (2008) found wood density increased with increasing tree height. Chowdhury et al. (2007) also observed no significant differences among heights (butt, centre, and crown) of Casuarina equisetifolia even though the density decreased by a 
small amount from butt to crown. Machado et al. (2014), working with 35-49 years old blackwood in Portugal, reported an increase in wood density with the height level especially from the $35 \%$ to the $65 \%$ tree height.

In the study, overall shrinkage and swelling percentage decreased from 1,30 $\mathrm{m}$ to $12,30 \mathrm{~m}$ except for longitudinal shrinkage and swelling percentage for both wood species. The highest volumetric shrinkage and swelling percentage were $16,90 \%$ and $20,40 \%$ for oriental beech, $12,28 \%$ and $12,69 \%$ for caucasian fir at $1,30 \mathrm{~m}$, respectively. Contrary to this declining trend, longitudinal shrinkage and swelling percentage increased from $1,30 \mathrm{~m}$ to $12,30 \mathrm{~m}$, reaching a maximum of $0,34 \%$ for oriental beech and $0,35 \%$ for caucasian fir. ANOVA (Duncan test, $P<0,05$ ) confirmed the statistically significant difference among stem heights for both wood species (Table 3). Kiaei (2011) found volumetric shrinkage and volumetric swelling of Zelcova carpinifolia grown in Iran decreased along longitudinal direction from the base to the top stem height. Similarly, Kord et al. (2010) reported that within tree longitudinal, radial, tangential, and volumetric shrinkage of Populus euramericana decreased along the stem from the base to the upwards. Rodrigo et al. (2013) reported a downward trend in volumetric shrinkage of Abies alba from the base to the crown. For 27 year-old Pinus radiata trees in New Zealand, Wang et al. (2008) reported that the longitudinal shrinkage decreased with the stem height, but tangential and radial shrinkage did not show a clear trend along the stem height. Moreover, Ay et al. (2012) found the shrinkage and swelling percentage (tangential and volumetric) of Larix decidua reached maximum values at $9 \mathrm{~m}$ in height, and then drop towards to $18 \mathrm{~m}$. Also, longitudinal shrinkage and swelling percentage do not have a clear trend in vertical direction. Chowdhury et al. (2007) studied physical properties of 25 year-old Casuarina equisetifolia at three different heights (butt, centre, and crown). They found that radial and longitudinal shrinkage did not vary significantly with increasing tree height, but tangential shrinkage did vary significantly and crown wood had greater shrinkage than wood from the other two heights. Contrary to these findings, the insignificant of vertical position on shrinkage values (tangential, radial, and volumetric) of grand fir was reported by Lukašek et al. (2012).

\section{Compression strength parallel to grain}

Compression strength parallel to grain values of the specimens and summary of variance analysis are given in Table 2 and Table 3. The highest compression strength was found to be 59,26 MPa at 1,30 $\mathrm{m}$ for oriental beech, and the lowest compression strength was found to be $33,02 \mathrm{MPa}$ at $12,30 \mathrm{~m}$ for caucasian fir, while there was no difference between the other two stem heights. This pattern showed that there was a decreased trend from at $1,30 \mathrm{~m}$ to $12,30 \mathrm{~m}$ in compression strength for both of wood species. Machado and Cruz (2005) observed a decrease from stem butt to top in compression strength of maritime pine depending on distance to the pith, emphasizing the strong influence of juvenile wood. As reported by Zobel and van Buijtenen (1989), the top logs contain mainly juvenile wood, which has low specific gravity and strength, butt logs from the same tree consist predominantly of mature wood. Also, Izekor et al. (2010) observed a decreasing trend from base to top in compression strength of Tectona grandis wood. In contrast to these findings, Kiaei (2011) found that the longitudinal direction has no effect on compression strength parallel to the grain of Zelcova carpinifolia grown in Iran, and Machado et al. (2014) reported that the compression strength of blackwood grown in Portugal did not vary with tree stem height (5\%,35\% and $65 \%$ of tree height). Density is the most important physical characteristic determining the compression strength of a wood sample, and a significant correlation between density and compression strength exists (Gindl and Teischinger 2002). Moreover, there are more material distributed internal stresses in dense wood, so the mechanical properties of wood are also increasing (Baar et al. 2015). In the present study, a declining trend from at $1,30 \mathrm{~m}$ to $12,30 \mathrm{~m}$ in density and compression strength for both wood species can be related to above mentioned correlation.

\section{Chemical properties}

Wood chemical components (holocellulose, cellulose and lignin) are summarized in Table 4. 
Table 4. Chemical properties of wood specimens

\begin{tabular}{lccccccc}
\hline \multirow{2}{*}{$\begin{array}{c}\text { Chemical } \\
\text { properties }\end{array}$} & Unit & \multicolumn{3}{c}{ Oriental beech } & \multicolumn{5}{c}{ Caucasian fir } \\
\cline { 3 - 8 } & & 1,30 & 6,30 & 12,30 & 1,30 & 6,30 & 12,30 \\
\hline Holocellulose & $\%$ & 75,55 & 75,28 & 76,41 & 75,38 & 76,73 & 77,04 \\
& & $(0,02)^{b^{*}}$ & $(0,39)^{\mathrm{c}}$ & $(0,09)^{\mathrm{a}}$ & $(0,40)^{\mathrm{y}}$ & $(0,63)^{\mathrm{x}}$ & $(0,08)^{\mathrm{x}}$ \\
Celluluse & $\%$ & 54,30 & 52,69 & 51,26 & 64,57 & 64,65 & 63,01 \\
& & $(0,25)^{\mathrm{a}}$ & $(0,19)^{\mathrm{b}}$ & $(0,17)^{\mathrm{c}}$ & $(0,44)^{\mathrm{x}}$ & $(0,24)^{\mathrm{x}}$ & $(0,53)^{\mathrm{y}}$ \\
Lignin & $\%$ & 20,28 & 20,94 & 21,52 & 28,15 & 28,49 & 29,53 \\
& & $(0,07)^{\mathrm{c}}$ & $(0,16)^{\mathrm{b}}$ & $(0,21)^{\mathrm{a}}$ & $(0,14)^{\mathrm{z}}$ & $(0,09)^{\mathrm{y}}$ & $(0,19)^{\mathrm{x}}$ \\
\hline
\end{tabular}

*Values in parentheses are standard deviations.

Different letters (a-c) and (x-z) within a line indicate significant differences between heights at $95 \%$ confidence level

Analysis of variance showed that there were significant differences $(P<0,05: P<0,01)$ among the stem heights for both wood species (Table 6). Hemicellulose, cellulose and lignin are the constituent polymers of wood, and are responsible for most of the physical, chemical and strength properties of wood and wood products (Pandey 1999). The lowest holocellulose content of oriental beech and caucasian fir was $75,28 \%$ at $6,30 \mathrm{~m}$ and $75,38 \%$ at $1,30 \mathrm{~m}$, respectively. While the holocellulose content of oriental beech increased from $6,30 \mathrm{~m}$ to $12,30 \mathrm{~m}$ stem height, the holocellulose content of caucasian fir increased from 1,30 m to $12,30 \mathrm{~m}$ stem height. Campbell et al. (2007) found that the holocellulose content in both varieties of lodgepole pine increased to about $20-30 \%$ stem height, they stated that this increase is possibly related to the higher percentage of hemicellulose in the juvenile wood in the top of the tree. The lignin content showed an increasing trend with increasing stem height, reached highest amounts at 12,30 m in both wood species. Campbell et al. (2007) observed the lignin content in both varieties of lodgepole pine increased from $0 \%$ to $20 \%$ stem height and then remained stable at higher stem heights. They stated that the increase in lignin with stem height is possibly related to higher percentage of juvenile wood in the upper stem. Moreover, Zobel and Sprague (2012) stated that juvenile wood is comprised nearest the pith at all heights in the tree and the tops of trees, regardless of tree age, have mainly juvenile wood. In contrast to the increasing trend in holocellulose and lignin content, cellulose content of oriental beech and caucasian fir decreased from $54,30 \%$ at $1,30 \mathrm{~m}$ to $51,26 \%$ at $12,30 \mathrm{~m}$ and $64,57 \%$ at $1,30 \mathrm{~m}$ to $63,01 \%$ at $12,30 \mathrm{~m}$ stem height, respectively. A decrease in the alpha-cellulose content of latifolia, which is the variety of lodgepole pine, was reported by Campbell et al. (2007). Furthermore, they concluded that the decrease in alpha-cellulose with stem height is associated with an increase in juvenile wood, an increase in hemicellulose, and a decrease in specific gravity. In the present study, the decrease in wood density and compression strength with increasing of stem height for both wood species can be related to the decrease in cellulose content with stem height. As known, cellulose is the main chemical component (Neagu et al. 2006), and one of the function of the cellulose is to provide the required strength in plant cells (Khalil et al. 2015). Moreover, Bergander and Salmén (2002) concluded that the elastic properties in the longitudinal direction of the cell wall are almost only determined by the elastic constants of cellulose.

\section{Fiber dimensions}

Fiber dimensions of oriental beech and caucasian fir are shown in Table 5. Significant differences were observed in fiber dimensions among stem heights (Table 6). 
Table 5. Fiber dimensions of wood specimens.

\begin{tabular}{|c|c|c|c|c|c|c|c|}
\hline \multirow{3}{*}{$\begin{array}{l}\text { Fiber } \\
\text { dimensions }\end{array}$} & \multirow{3}{*}{ Unit } & \multicolumn{3}{|c|}{ Oriental beech } & \multicolumn{3}{|c|}{ Caucasian fir } \\
\hline & & \multicolumn{6}{|c|}{ Stem height (m) } \\
\hline & & 1,30 & 6,30 & 12,30 & 1,30 & 6,30 & 12,30 \\
\hline Fiber length & $\mathrm{mm}$ & $\begin{array}{c}1,02 \\
(0,19)^{a^{4}}\end{array}$ & $\begin{array}{c}0,96 \\
(0,15)^{\mathrm{ab}}\end{array}$ & $\begin{array}{c}0,93 \\
(0,19)^{b}\end{array}$ & $\begin{array}{c}2,67 \\
(0,35)^{x}\end{array}$ & $\begin{array}{c}2,31 \\
(0,58)^{y}\end{array}$ & $\begin{array}{c}2,47 \\
(0,58)^{x y}\end{array}$ \\
\hline Fiber width & $\mu \mathrm{m}$ & $\begin{array}{l}21,08 \\
(5,64)^{\mathrm{a}}\end{array}$ & $\begin{array}{c}17,10 \\
(3,55)^{b}\end{array}$ & $\begin{array}{l}20,45 \\
(3,49)^{\mathrm{a}}\end{array}$ & $\begin{array}{l}33,88 \\
(8,24)^{y}\end{array}$ & $\begin{array}{c}36,95 \\
(7,40)^{x}\end{array}$ & $\begin{array}{c}35,92 \\
(8,13)^{x}\end{array}$ \\
\hline $\begin{array}{l}\text { Fiber lumen } \\
\text { width }\end{array}$ & $\mu \mathrm{m}$ & $\begin{array}{c}8,27 \\
(2,78)^{b}\end{array}$ & $\begin{array}{c}7,05 \\
(2,15)^{c}\end{array}$ & $\begin{array}{l}12,00 \\
(2,73)^{\mathrm{a}}\end{array}$ & $\begin{array}{l}20,47 \\
(5,60)^{2}\end{array}$ & $\begin{array}{c}24,90 \\
(6,76)^{y}\end{array}$ & $\begin{array}{c}27,17 \\
(6,09)^{x}\end{array}$ \\
\hline $\begin{array}{l}\text { Fiber wall } \\
\text { thickness }\end{array}$ & $\mu \mathrm{m}$ & $\begin{array}{c}6,40 \\
(2,50)^{\mathrm{a}}\end{array}$ & $\begin{array}{c}5,03 \\
(1,90)^{b}\end{array}$ & $\begin{array}{c}4,23 \\
(1,97)^{c}\end{array}$ & $\begin{array}{c}6,71 \\
(2,19)^{x}\end{array}$ & $\begin{array}{c}6,03 \\
(1,81)^{y} \\
\end{array}$ & $\begin{array}{c}4,37 \\
(1,75)^{z}\end{array}$ \\
\hline
\end{tabular}

"Values in parentheses are standard deviations.

Different letters (a-c) and (x-z) within a line indicate significant differences between heights at $95 \%$ confidence level.

Table 6. Summary of variance analysis for chemical properties and fiber dimensions.

\begin{tabular}{|l|c|c|}
\hline \multirow{2}{*}{ Wood properties } & \multicolumn{2}{|c|}{ Significant level $(P)$} \\
\cline { 2 - 3 } & Oriental beech & Caucasian fir \\
\hline Holocellulose & 0,000 & 0,000 \\
\hline Cellulose & 0,000 & 0,000 \\
\hline Lignin & 0,000 & 0,000 \\
\hline Fiber length & 0,029 & 0,028 \\
\hline Fiber width & 0,000 & 0,002 \\
\hline Fiber lumen width & 0,000 & 0,000 \\
\hline Fiber wall thickness & 0,000 & 0,000 \\
\hline
\end{tabular}

As shown in Table 5, the fiber length was found to be 0,93-1,02 $\mathrm{mm}$ and 2,31-2,67 $\mathrm{mm}$ for oriental beech and caucasian fir, respectively. As known, fiber length is a valuable determinant of paper strength, and hardwood fibers are significantly shorter than softwood tracheids (Shmulsky and Jones 2011). Fiber length slightly decreased from $1,30 \mathrm{~m}$ to $12,30 \mathrm{~m}$ along with the stem height for both of wood species. The decrease of wood fiber length to the top was described for Eucalyptus globulus by Jorge et al. (2000), who found a small decrease in wood fiber length from base to top. Tavares et al. (2011) also found a slight decrease in fiber length of Acacia melanoxylon, from $0,97 \mathrm{~mm}$ to $0,91 \mathrm{~mm}$ at $5 \%$ and $65 \%$ of total tree height, respectively. Bhat et al. (2007) observed that there was a small increase in fiber length of Eucalyptus grandis from stump level to $25 \%$ of tree height level and then a decrease towards the top. The decrease in fiber length with stem height is because the tree top of an old tree consists basically of juvenile wood which has shorter fibers (Zobel and van Buijtenen 1989). In contrast to our findings, Gominho et al. (2015) found that fiber length of unbleached Eucalyptus globulus pulps increased from $827 \mu \mathrm{m}$ at $0 \%$ to $877 \mu \mathrm{m}$ at $50 \%$ height levels. Moreover, Molteberg and Høibø (2006) observed that fiber length of Picea abies increased with increasing height in the tree, and concluded to be closely related to cambium age. Adamopoulos et al. (2010) reported that cambium age and growth rate are principal factors affecting wood properties, mainly cell dimensions and density in both gymnosperm and angiosperm species. There is also a direct relationship between 
fiber morphology and paper properties (Azeez et al. 2016).

The fiber width initially decreased from $21,08 \mu \mathrm{m}$ at $1,30 \mathrm{~m}$ to $17,10 \mu \mathrm{m}$ at $6,30 \mathrm{~m}$, and then increased to $20,45 \mu \mathrm{m}$ at $12,30 \mathrm{~m}$ stem height for oriental beech. The fiber width of caucasian fir showed a general increasing trend from 33,88 $\mu \mathrm{m}$ to $35,92 \mu \mathrm{m}$. Gominho et al. (2015) found that fiber width of unbleached Eucalyptus globulus pulps decreased from $19 \mu \mathrm{m}$ at $0 \%$ to $17 \mu \mathrm{m}$ at $50 \%$ height levels. For oriental beech, the fiber lumen width first decreased from $8,27 \mu \mathrm{m}$ at $1,30 \mathrm{~m}$ to $7,05 \mu \mathrm{m}$ at $6,30 \mathrm{~m}$ and then strongly increased to $12,00 \mu \mathrm{m}$ at $12,30 \mathrm{~m}$. For caucasian fir, the fiber lumen width strongly increased from $20,47 \mu \mathrm{m}$ at $1,30 \mathrm{~m}$ to $27,17 \mu \mathrm{m}$ at $12,30 \mathrm{~m}$. The fiber wall thickness decreased from $6,40 \mu \mathrm{m}$ at $1,30 \mathrm{~m}$ to $4,23 \mu \mathrm{m}$ at $12,30 \mathrm{~m}$ and from $6,71 \mu \mathrm{m}$ at $1,30 \mathrm{~m}$ to $4,37 \mu \mathrm{m}$ at $12,30 \mathrm{~m}$ stem height for oriental beech and caucasian fir, respectively. Molteberg and Høibø (2006) observed the fiber width of Picea abies decreased with increasing height in the tree, fiber wall thickness was not affected by tree height.

In present study, for both wood species the decreasing trend in density with increasing stem height could possibly be related to the decrease in fiber wall thickness. Moreover, Cato et al. (2006) reported that wood at the crown had a lower density due to reduced cell wall thickness at the crown of the tree. The decrease in density, compression strength, fiber length, fiber wall thickness, and the increase in longitudinal shrinkage and lignin content for both wood species indicate the presence of juvenile wood. As reported by Langum et al. (2009), the main factors lead to less strength, decreasing stiffness, and increasing longitudinal shrinkage are low density, short fibers, thinner cell walls, and higher microfibril angles in juvenile wood. Wood properties vary at different heights in the tree because the proportion of juvenile wood increases largely from the base to the top (Zobel and van Buijtenen 1989). Especially, the determining of the wood properties of the butt and top logs of commercial timber species is an important issue for wood users. Therefore, juvenile and mature wood need to be studied separately to better understand the changes of wood properties with the height in the tree.

\section{CONCLUSIONS}

In this study the longitudinal variation of several wood properties of oriental beech and caucasian fir stems was investigated. Wood density, compression strength, shrinkage and swelling percentage except for longitudinal shrinkage and swelling percentage decreased clearly from $1,30 \mathrm{~m}$ to $12,30 \mathrm{~m}$ stem height and the difference among stem heights was significant for both wood species. The content of lignin increased while the content of cellulose decreased along the stem height in both wood species. Significant differences were observed along the stem height in fiber dimensions of both wood species. Fiber wall thickness strongly decreased along the stem height in both wood species. An understanding of longitudinal variation in wood properties is important for forest product industries because it provides the differentiation of raw material in the production phase. This obtained information could be useful to wood users of beech used in the production of bentwood furniture, veneer, plywood, and fir used in the production of wooden panels, joinery, and plywood in forest products.

\section{REFERENCES}

Adamopoulos, S.; Chavenetidou, M.; Passialis, C.; Voulgaridis, E. 2010. Effect of cambium age and ring width on density and fibre length of black locust and chestnut wood. Wood Research 55 
(3): 25-36.

Antony, F.; Schimleck, L.R.; Daniels, R.F.; Clark III, A.; Hall, D.B. 2010. Modeling the longitudinal variation in wood specific gravity of planted loblolly pine (Pinus taeda) in the United States. Canadian Journal of Forest Research 40: 2439-2451.

Ay, N.; Topaloglu, E.; Akpınar, E. 2012. The effects of stem height on the physical properties of European larch (Larix decidua Mill.) wood. Innovations in Forest Industry and Engineering Design, November 15-17, Yundola, Bulgaria.

Azeez, M.A.; Andrew, J.E.; Sithole, B. 2016. Preliminary investigation of Nigerian Gmelina arborea and Bambusa vulgaris for pulp and paper production. Maderas-Cienc Tecnol 18(1):65-78.

Baar, J.; Tippner, J.; Rademacher, P. 2015. Prediction of mechanical properties - modulus of rupture and modulus of elasticity - of five tropical species by nondestructive methods. Maderas-Cienc Tecnol 17(2): 239-252.

Bektas, İ.; Guler, C. 2001. The determination of some physical properties of beech wood (Fagus orientalis Lipsky.) in the Andırın region. Turkish Journal of Agriculture and Forestry 25: 209-215.

Bergander, A.; Salmén, L. 2002. Cell wall properties and their effects on the mechanical properties of fibers. Journal of Materials Science 37 (1): 151-156.

Bhat, K.M.; Bhat, K.V.; Dhamodaran, T.K. 2007. Wood density and fiber length of Eucalyptus grandis grown in Kerala, India. Wood and Fiber Science 22 (1): 54-61.

Bozkurt, A.Y.; Erdin, N. 1997. Wood Technology. Istanbul University Publication No: 3998, Faculty of Forestry Publication No: 445, ISBN: 975-404-449-X

Browning, B.L. 1967. Methods of Wood Chemistry. Vol. II. John Wiley and Sons Inc. New York.

Campbell, A.G.; Kim, W.J.; Koch, P. 2007. Chemical variation in lodgepole pine with sapwood/ heartwood, stem height, and variety. Wood and Fiber Science 22 (1): 22-30.

Cato, S.; McMillan, L.; Donaldson, L.; Richardson, T.; Echt, C.; Gardner, R. 2006. Wood formation from the base to the crown in Pinus radiata: gradients of tracheid wall thickness, wood density, radial growth rate and gene expression. Plant Molecular Biology 60: 565-581.

Chowdhury, M.Q.; Rashid, A.Z.M.M.; Newaz, M.S.; Alam, M. 2007. Effects of height on physical properties of wood of jhau (Casuarina equisetifolia). Australian Forestry 70 (1): 33-36.

Fengel, D.; Wegener, G. 1989. Isolation and Determination of Cellulose; Chemical Composition and Analysis of Wood. In Wood-Chemistry, Ultrastructure, Reactions. Walter de Gruyter \& Co.

Gindl, W.; Teischinger, A. 2002. Axial compression strength of Norway spruce related to structural variability and lignin content. Composites Part A: Applied Science and Manufacturing 33 (12): 16231628.

Githiomi, J.K.; Kariuki, J.G. 2010. Wood basic density of Eucalyptus grandis from plantations in central rift valley, Kenya: Variation with age, height level and between sapwood and heartwood. Journal of Tropical Forest Science 22 (3): 281-286.

Gominho, J.; Lourenço, A.; Neiva, D.; Fernandes, L.; Amaral, M.E.; Duarte, A.P.; Simoes, R.; Pereira, H. 2015. Variation of Wood Pulping and Bleached Pulp Properties Along the Stem in Mature Eucalyptus globulus Trees. BioResources 10 (4): 7808-7816.

International Organization for Standardization. ISO. 1975. Wood-determination of density for physical and mechanical tests. ISO 3131: 1975 
International Organization for Standardization. ISO. 1976. Wood-determination of ultimate stress in compression parallel to grain. ISO 3787: 1976.

International Organization for Standardization. ISO. 1981. Wood-determination of radial and tangential shrinkage. ISO 4469: 1981.

International Organization for Standardization. ISO. 1982. Wood-determination of volumetric shrinkage. ISO 4858: 1982.

International Organization for Standardization. ISO. 1982. Wood-determination of radial and tangential swelling. ISO 4859: 1982.

International Organization for Standardization. ISO. 1982. Wood-determination of volumetric swelling. ISO 4860: 1982.

International Organization for Standardization. ISO. 1976. Standard atmospheres for conditioning and/or testing; specifications. ISO 554: 1976.

Izekor, D.N.; Fuwape, J.A.; Oluyege, A.O. 2010. Effects of density on variations in the mechanical properties of plantation grown Tectona grandis wood. Archives of Applied Science Research 2(6): 113120.

Jorge, F.; Quilhó, T.; Pereira, H. 2000. Variability of fiber length in wood and bark in Eucalyptus globulus. IAWA Journal 21 (1): 41-48.

Jyske, T.; Mäkinen, H.; Saranpää, P. 2008. Wood density within Norway spruce stems. Silva Fennica 42(3): 439-455.

Karasahin, H.; Tulukcu, M.; Sengun, S.; Nur, M. 2002. The Seed Productivity of Cones of Nordmann's Fir (Abies nordmanniana (Stev.)Spach.). Technical bulletin no: 9, Forest Tree Seeds and Tree Breeding Research Directorate, Ankara, Turkey.

Khalil, H.A.; Hossain, M.S.; Rosamah, E.; Azli, N.A.; Saddon, N.; Davoudpoura, Y.; Islam M.N.; Dungani, R. 2015. The role of soil properties and it's interaction towards quality plant fiber: A review. Renewable and Sustainable Energy Reviews 43: 1006-1015.

Kiaei, M. 2011. Variation in the Wood Physical and Mechanical Properties of Zelcova carpinifolia Trees along Longitudinal Direction, Middle-East Journal of Scientific Research 9 (2): 279-284.

Kiaei, M.; Farsi, M. 2016. Vertical variation of density, flexural strength and stiffness of Persian silk wood. Madera y Bosques 22 (1): 169-175.

Kord, B.; Kialashaki, A.; Kord, B. 2010. The within-tree variation in wood density and shrinkage, and their relationship in Populus euramericana. Turkish Journal of Agriculture and Forestry 34: 121126.

Lachenbruch, B.; McCulloh, K.A. 2014. Traits, properties, and performance: how woody plants combine hydraulic and mechanical functions in a cell, tissue, or whole plant. New Phytologist 204: 747-764.

Lachenbruch, B.; Moore, J.R.; Evans, R. 2011. Radial variation in wood structure and function in woody plants, and hypotheses for its occurrence Size- and age-related changes in tree structure and function (eds F.C.C. Meinzer, B. Lachenbruch \& T.E.E. Dawson), pp. 121 164. Springer Netherlands.

Langum, C.E.; Yadama, V.; Lowell, E.C. 2009. Physical and mechanical properties of young- 
growth Douglas-fir and western hemlock from western Washington. Forest Products Journal 59 (11): $37-47$.

Longui, E.L.; Gondo, C.C.S.; Luiz de Lima, I.; Freitas, M.L.M.; Florsheim, S.M.B.; Zanatto, A.C.S.; Garcia, J.N. 2016. Some Properties of Astronium graveolens Wood Along the Stem. Floresta e Ambiente 23 (1): 142-149.

Lukašek, J.; Zeidler, A.; Barcik, ک̌. 2012. Shrinkage of Grand fir wood and its variability within the stem. Drvna industrija 63 (2): 121-128.

Machado, J.S.; Cruz, H.P. 2005. Within stem variation of Maritime pine timber mechanical properties. Holz als Roh-und Werkstoff 63 (2): 154-159.

Machado, J.S.; Louzada, J.L.; Santos, A.J.; Nunes, L.; Anjos, O.; Rodrigues, J.; Simoes, M.S.; Pereira, H. 2014. Variation of wood density and mechanical properties of blackwood (Acacia melanoxylon R. Br.). Materials and Design 56: 975-980.

Mahmud, S.Z.; Hashim, R.; Saleh, A.H.; Sulaiman, O.; Saharudin, N.I.; Ngah, M.L.; Masseat, K.; Husain, H. 2017. Physical and mechanical properties of juvenile wood from Neolamarckia cadamba planted in west Malaysia. Maderas-Cienc Tecnol 19 (2): 225-238.

Molteberg, D.; Høibø, O. 2006. Development and variation of wood density, kraft pulp yield and fiber dimensions in young Norway spruce (Picea abies). Wood Science and Technology 40: 173-189.

Neagu, R.C.; Gamstedt, E.K.; Bardage, S.L.; Lindström, M. 2006. Ultrastructural features affecting mechanical properties of wood fibers. Wood Material Science and Engineering 1: 146-170.

Pandey, K.K. 1999. A study of chemical structure of soft and hardwood and wood polymers by FTIR spectroscopy. Journal of Applied Polymer Science 71: 1969-1975.

Repola, J. 2006. Models for vertical wood density of Scots pine, Norway spruce and Birch stems, and their application to determine average wood density. Silva Fennica 40 (4): 673-685.

Rodrigo, B.G.; Esteban, L.G.; de Palacios, P.; Fernández, F.G.; Casasús, A.G. 2013. Variation throughout the tree stem in the physical-mechanical properties of the wood of Abies alba Mill. from the Spanish Pyrenees. Madera y Bosques 19 (2): 87-107.

Rosner, S. 2013. Hydraulic and biomechanical optimization in Norway spruce trunkwood - A review. IAWA Journal 34 (4): 365-390.

Rosner, S.; Karlsson B. 2011. Hydraulic efficiency compromises compression strength perpendicular to the grain in Norway spruce trunkwood. Trees 25: 289-299.

Rueda, R.; Williamson, G.B. 1992. Radial and vertical specific gravity in Ochroma pyramidale (Cav. ex Lam.) Urb. (Bombacaceae). Biotropica 24 (4): 512-518.

Saranpää, P. 2003. Wood density and growth. In J. R. Barnett and G. Jeronimidis (Eds.), Wood Quality and its Biological Basis. USA, CRC Press.

Shmulsky, R.; Jones, P.D. 2011. Forest Products and Wood Science. 6 edition. John Wiley \& Sons: Chichester, UK

TAPPI standard. 2007. Solvent Extractives of Wood and Pulp. T $204 \mathrm{~cm}-07$

TAPPI standard. 2011. Acid-Insoluble Lignin in Wood and Pulp. T 222 om-11

TAPPI standard. 2012. Sampling and Preparing Wood for Analysis. T 257 cm-12 
Tavares, F.; Quilhó, T.; Pereira, H. 2011. Wood and bark fiber characteristics of Acacia melanoxylon and comparison to Eucalyptus globulus. Cerne 17 (1): 61-68.

Topaloglu, E.; Ay, N.; Altun, L.; Serdar, B. 2016. Effect of altitude and aspect on various wood properties of Oriental beech (Fagus orientalis Lipsky) wood. Turkish Journal of Agriculture and Forestry 40 (3): 397-406.

Usta, İ. 2004. The Effect of Moisture Content and Wood Density on the Preservative Uptake of Caucasian fir (Abies nordmanniana (Link.) Spach.) Treated with CCA. Turkish Journal of Agriculture and Forestry 28: 1-7.

Wang, E.; Chen, T.; Pang, S.; Karalus, A. 2008. Variation in anisotropic shrinkage of plantationgrown Pinus radiata wood. Maderas-Cienc Tecnol 10 (3): 243-249.

Wiedenhoeft, A.C.; Miller, R.B. 2005. Structure and function of wood. Handbook of wood chemistry and wood composites. 9-33.

Wise, L.E.; Murphy, M.; D'Addieco, A.A. 1946. Chlorite holocellulose, its fractionation and bearing on summative wood analysis and on studies on the hemicelluloses. Paper Trade Journal 122 (2): $35-43$.

Yu, M.; Cheng, X.; He, Z.; Wu, T.; Yin, Z. 2014. Longitudinal Variation of Ring Width, Wood Density and Basal Area Increment in 26-Year-Old Loblolly Pine (Pinus taeda) Trees. Tree-Ring Research 70 (2): 137-144.

Zeidler, A. 2012. Variation of wood density in Turkish hazel (Corylus colurna L.) grown in the Czech Republic. Journal of Forest Science 58 (4): 145-151. Media.

Zobel, B.J.; Sprague, J.R. 2012. Juvenile wood in forest trees. Springer Science \& Business

Zobel, B.J.; van Buijtenen, J.P. 1989. Wood Variation and Wood Properties. In: Wood Variation: Its Causes and Control. Springer: Berlin Heidelberg. 


\section{LIST OF ABBREVIATIONS}

$\begin{array}{ll}\mathrm{N} & \text { North } \\ \mathrm{E} & \text { East } \\ \mathrm{D}_{12} & \text { Air-dry density } \\ \beta_{t} & \text { Tangential shrinkage percentage } \\ \beta_{r} & \text { Radial shrinkage percentage } \\ \beta_{l} & \text { Longitudinal shrinkage percentage } \\ \beta_{v} & \text { Volumetric shrinkage percentage } \\ \alpha_{t} & \text { Tangential swelling percentage } \\ \alpha_{r} & \text { Radial swelling percentage } \\ \alpha_{l} & \text { Longitudinal swelling percentage } \\ \alpha_{v} & \text { Volumetric swelling percentage } \\ \text { ISO } & \text { International Organization for Standardization } \\ C S & \text { Compression strength parallel to the grain } \\ \text { TAPPI } & \text { Technical Association of the Pulp and Paper Industry } \\ P & \text { Significant level }\end{array}$

